\title{
Емпіричне дослідження впливу новизни діяльності на розвиток самоактуалізації психолога
}

\author{
Олег Бабелюк * А; Наталія Гоцуляк А; Володимир Ізрайлов ${ }^{\text {; }}$ \\ Олексій Шкуренко ${ }^{B}$ \\ А Кам'янець-Подільський національний університет імені Івана Огієнка, вул. Огієнка, 61, Кам'янець-Подільський, 32301, Україна

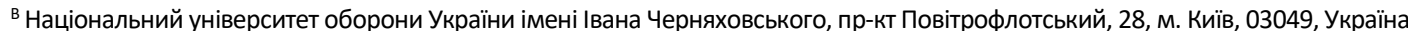

Received: October 18, 2020 | Revised: October 27, 2020 | Accepted: October 31, 2020

DOI: $10.33445 /$ sds.2020.10.5.16

\begin{abstract}
Анотація
Стаття присвячена встановленню взаємозв'язку між новизною діяльності та рівнем розвитку самоактуалізації психолога.

Проведено аналіз наукових робіт в цій галузі і визначено, що самоактуалізація - це психологічних процес, при якому здібності людини застосовуються повністю та творчо, а також самоактуалізація дає людині почуття задоволеності в житті.

Авторами пропонуються концептуальні підходи щодо емпіричного дослідження впливу різних чинників на розвиток самоактуалізації професіонала.

Говорячи про роль новизни діяльності, автори дослідження наголошують на проблемі інформаційного конфлікту. Термін “інформаційний конфлікт” позначає пізнавальний стан суб'єкта в ситуації ідентифікації, або віднесення його до категорії стимульной конфігурації, частини якої не погоджуються одна з одною, перебуваючи у стані жорсткого протиріччя.

За отриманими результатами автори зробити висновки, що мотиваційний чинник - новизна діяльності - впливає на розвиток самоактуалізації особистості й ефективніше результати видно після спеціально проведених тренінгів.

В подальшому пропонується провести дослідження впливу середовища на самоактуалізацію фахівця.
\end{abstract}

Ключові слова: діяльність, самоактуалізація, креативність, інформаційний конфлікт, психолог, особистість.

\section{Постановка проблеми}

В умовах розвитку сучасного суспільства дослідження психологічних особливостей розвитку самоактуалізації особистості набуває все більшого значення. Самоактуалізація $€$ важливою складовою людського бутяя, оскільки наповнює житя людини спрямованістю та сенсом, саме завдяки самоактуалізації особистість здійснює професійний саморозвиток, розкриває свої Аналіз останніх досліджень та публікацій

Дослідженню проблем самоактуалізації особистості присвячені праці представників гуманістичної психології - А. Маслоу, К. Роджерса, Г. Олпорта, В. Франкла, Р. Мея та ін. У центрі наукової уваги гуманістичних психологів знаходиться творча особистість, метою якоїє самореалізація та розкритяя особистісного потенціалу. У вітчизняній психології самоактуалізація розглядається як проблема становлення особистості, а також вивчається у взаємозв'язку з процесами самореалізації, саморозвитку особистості та представлена у працях С. Л. Рубінштейна, Б. Г. Ананьєва, К. О. Абульханова-Славської, Б. С.

\footnotetext{
* кандидат психологічних наук, викладач кафедри військової підготовки, e-mail: babeliyk@ukr.net
} 
Братуся, М. Й. Боришевського, С. Д. суб'єкта власної життдіяльності, Максименка, В. О. Моляко, В. О. Татенка, Т. М. життетворчості та творця свого неповторного Титаренко та ін., які розглядають життвого світу. самоактуалізовану особистість як активного

Постановка завдання

Метою статті $\boldsymbol{\epsilon}$ емпірично дослідити психологічні особливості впливу новизни

діяльності на розвиток самоактуалізації психолога.

\section{Виклад основного матеріалу}

у сучасній психології самоактуалізацію визначають як найбільш повну та вільну самореалізацію особистістю своїх можливостей. Самоактуалізація $є$ вродженою тенденцією людини до безперервного розгортання свого необмеженого творчого потенціалу в різних сферах життдіяльності. Згідно поглядів представників гуманістичного напрямку в психології, самоактуалізація $\epsilon$ інтегральною якістю особистості та найважливішим механізмом їі розвитку. Самоактуалізація - це завжди реальні вчинки, які виражають особистісну активність та відповідальність, здатність до своєчасного та оптимального життєвого вибору. Втілення в життя власних задумів та планів відкриває перед людиною нові можливості, виводячи особистість на новий рівень розвитку, перетворюючи та змінюючи ї̈ життвий світ. Самоактуалізація передбачає максимальне самовираження особистості, тобто реалізацію власних здібностей та потенційних можливостей, що гармонійно впливає на становлення особистості (Артемова, 2010). Першим ввів у науковий обіг поняття "самоактуалізація" нейрофізіолог А.Ю. Василенко з метою філософського визначення універсального принципу житя, основного і єдиного мотиву в людському житті. Відмінності в напрямках і цілях самоактуалізації зумовлені різними внутрішніми потенціями людей i відмінностями в перешкодах, які виникають на шляху особистості, що самоактуалізується в зовнішньому оточенні. Подолання цих перешкод призводить або до пристосування до середовища, або до оволодіння ним, знаходження більш ефективних способів поведінки (Василенко, 2018). Як ми бачимо, розвиток i вдосконалення людини безпосередньо пов'язані із соціальними відносинами. У свої працях А. Маслоу розглядав людину як активного творця власної особистості та свого стилю житя. Людина визначається прагненням до самовдосконалення та саморозвитку. Сама сутність людини зумовлює її постійний рух до творчості та самодостатності. Фундаментальною позицією гуманістичної психології $\epsilon$ визнання пріоритетності творчого потенціалу людини. А. Маслоу перший висловив тезу, що творчість $€$ універсальною характеристикою людини, їі невід'ємною сутністю. Творчі здібності притаманні людині від народження. Творчість - універсальна функція людини, що передбачає всі види саморозкриття особистості. Здатність до творчості закладена в кожній людині, для творчості не потрібні якісь особливі обдарування або навички. В процесі творчого самовираження людина розкриває себе, свій внутрішній світ, вносить щось нове та неповторне в оточуючу дійсність (Гомонюк, 2016). А. Маслоу головною характеристикою особистості вважав прагнення до самоактуалізації, самовираження, до творчості та любові, в основі яких лежить гуманістична потреба змінювати світ на краще. Потреба в самоактуалізації своїх можливостей і здібностей властива здоровій, творчій людині. Прагнення до самоактуалізації у А. Маслоу виявляється вершиною піраміди ієрархії потреб. Самоактуалізація визначається як бажання людини максимально розвинути свої здібності, цілком розгорнути закладений природою потенціал. У процесі самоактуалізації особистість стає саме такою, якою вона може бути, і досягає вершини своїх можливостей (Сафронов, 2017). Самоактуалізація - це діючий 
процес, при якому здібності людини застосовуються повністю та творчо, а також самоактуалізація дає людині почуття задоволеності в житті. Креативність, спонтанність, природність, сміливість, незалежність, захопленість власною працею це основні якості самоактуалізованої особистості. Самоактуалізовані люди досягли того рівня особистісного розвитку, який потенційно закладений у кожному, вони живуть наповненим сенсом життям та здійснюють власне життєве призначення (Ткалич, 2006).

Діяльність, що спонукається дослідницькою потребою, має своїм результатом продуктивне, нове знання. Зарубіжні дослідники одностайні в тому, що основними об'єктивними факторами, що детермінують дослідницьку поведінку, $\epsilon$ новизна й складність. Саме в ситуації новизни проблема пошуку значення проявляє себе 3 найбільшою силою. Вчені виділяють кілька типів новизни. Перший тип припускає раптове порушення строгої послідовності ряду стимулів. Другий тип характеризується наявністю звичних, відомих речей у несподіваному місці. Об'єкти, що характеризуються новизною третього типу - зовсім нові й невідомі для суб'єкта явища.

Говорячи про роль новизни діяльності, сучасні автори наголошують на проблемі інформаційного конфлікту. Термін “інформаційний конфлікт" позначає пізнавальний стан суб'єкта в ситуації ідентифікації, або віднесення його до категорії стимульной конфігурації, частини якої не погоджуються одна з одною, перебуваючи у стані жорсткого протиріччя. Розв язання інформаційного конфлікту, ідентифікація стимулу відбувається в процесі дослідницької діяльності; значимість цього розв язання для життєдіяльності очевидна, адже від того, наскільки категоризація стимулу виявиться вірною й, відповідно, відповідь на середовищний вплив адекватним, залежить виживання організму.

Вивчаючи вплив мотиваційного механізму новизни діяльності на розвиток самоактуалізації особистості, ми задіяли в експерименті групу психологів у кількості 25 осіб. Результати рівня розвитку самоактуалізації особистості ми порівнювали з контрольною групою у кількості 25 осіб. Одним із засобів, які "занурювали" психологів у нову діяльність, що сприяє розвитку самоактуалізацї особистості, була колективно-творча діяльність.

Методика організації колективно-творчої справи (КТС) була розроблена І.П. Івановим. Справа ця є обов'язково колективною: спільно планується, готується, проводиться, оцінюється.

Іванов І. П. виділяє шість взаємозалежних стадій організації КТС.

1 стадія - попередня: визначення конкретних завдань майбутньої справи; може проводитися у формі “стартової бесіди”, під час якої керівник захоплює групу психологів перспективою потрібної, цікавої й корисної справи. Основні труднощі на цій стадії полягають у тому, що можуть виникнути утруднення у творчому підході до визначення мети, завдання, організаційних форм. I тоді керівник виступає як співавтор колективної думки, дає необхідний поштовх, ненав'язливо пропонує різні варіанти, з яких самі психологи виокремлюють колективну творчу ідею.

2-га стадія - колективне планування КТС, що відбувається на загальних зборах: спочатку висунуті ідеї розглядаються в мікроколективах (групах), де кожний висловлює свою думку; потім проводиться заключне обговорення. Ведучий збору співставляє висунуті представниками мікроколективів варіанти, задає уточнюючі питання, пропонує обґрунтувати пропозиції, аргументувати їньому опоненту, ставить додаткові творчі завдання, які теж спочатку вирішуються у мікроколективах, а потім спільно.

3-а стадія - колективна підготовка справи. Керівний орган КТС (рада справи, творча або ініціативна група) уточнює, конкретизує план підготовки, організує його виконання, усіляко заохочуючи ініціативу виконавців. Позиція керівника обмежується стимулюючою функцією. За його допомогою вирішуються найбільш складні організаційні моменти, він може виступати в ролі консультанта.

4-та стадія - проведення КТС, коли конкретний план, розроблений спільними зусиллями, втілюється у життя. 
5-та стадія - колективне підведення підсумків, коли ставляться такі питання: Що сподобалось? Що не вдалося здійснити? Які висновки варто зробити на майбутнє? При цьому важливо не стільки констатувати факти, скільки з'ясувати причини, що породили успіх або невдачу. Обговорення підсумків краще починати в мікроколективах, а потім продовжувати всім разом. Попередньо проводиться інтерв'ю або анкетування: Що нового Ви довідалися, зробили? Чому навчилися?

6-та стадія - найближчі наслідки справи, тобто виконання тих рішень, які були прийняті всією групою по гарячих слідах КТС: вносяться зміни У творчі доручення мікрогрупам, планується нова КТС.

Після закінчення проєкту був досліджений рівень потенціалу саморозвитку, рівні вербальної й невербальної креативності, які у підсумку дають нам картину розвитку самоактуалізації особистості на той момент.

Психологам, що входять в експериментальну групу, були проведені спеціальні тренінги, на яких фахівці поринали у середовище, наближене до професійної сфери. Результати цієї нової діяльності, найчастіше незвичної для психологів не тільки дозволяють розвинути їм самоактуалізацію, але й спробувати реалізувати свої здібності повною мірою.

Розглянемо спочатку гістограми складового параметра рівня розвитку самоактуалізації особистості (СО). Параметри самоактуалізації особистості за всіма тестовими показниками були розкладені на наступних рівнях:

"1" - показник дуже високого рівня самоактуалізації особистості (СО);

" 2 " - високий рівень СО;

"3" - вище за середній рівень СО;

"4" - середній рівень СО;

" 5 " - низький рівень СО;

"6" - дуже низький рівень СО.

Першою складовою параметра самоактуалізації особистості $\epsilon$ рівень творчого потенціалу (РТП) для експериментальної групи, на яку впливали мотиваційним засобом новизною діяльності і показники контрольної групи на всіх етапах експериментального дослідження.

Таблиця 1 - Рівень самоактуалізації психологів експериментальної групи

\begin{tabular}{|c|c|c|c|}
\hline $\begin{array}{c}\text { Рівень } \\
\text { Со }\end{array}$ & 1 етап дослідження & 2 етап дослідження & 3 етап дослідження \\
\hline 1 & 0 & 0 & 1 \\
\hline 2 & 0 & 0 & 0 \\
\hline 3 & 3 & 10 & 19 \\
\hline 4 & 19 & 14 & 5 \\
\hline 5 & 3 & 1 & 0 \\
\hline 6 & 0 & 0 & \\
\hline
\end{tabular}

Ми бачимо тенденцію підвищення рівня самоактуалізації на кожному етапі. На початковому - першому етапі експерименту: 3 рівень був у 3 психологів, 4 рівень - у 19 психологів, 5 рівень-у 3 психологів. На другому етапі на 3 рівні вже 10 психологів, на 4 рівні-14, на 5 - 1 психолог. На третьому етапі ми бачимо наступний результат: на 1 рівні - 1 психолог на 3- 19 психологів, на 4 рівні - 5 психологів, а фахівців з показниками 5рівня вже не спостерігається. Це дозволяє нам зробити висновок про те, що в експериментальній групі простежується тенденція розвитку самоактуалізації особистості. Результати контрольної групи дають нам можливість говорити про те, що немає явної відмінності в параметрах рівня самоактуалізації на початку експерименту й на третьому (заключному) його етапі, хоча незначні зміни можна простежити. 
Таблиця 2 - Рівень творчого потенціалу у психологів контрольної групи

\begin{tabular}{|c|c|c|c|}
\hline $\begin{array}{c}\text { Рівень } \\
\text { со }\end{array}$ & 1 етап дослідження & 2 етап дослідження & 3 етап дослідження \\
\hline 1 & 0 & 0 & 0 \\
\hline 2 & 0 & 0 & 0 \\
\hline 3 & 2 & 4 & 4 \\
\hline 4 & 14 & 16 & 17 \\
\hline 5 & 9 & 5 & 0 \\
\hline 6 & 0 & 0 & \\
\hline
\end{tabular}

Іншою складовою параметра самоактуалізації особистості $€$ рівень вербальної креативності (РВК). Дані експериментальної групи, на яку впливали мотиваційним засобом - новизною діяльності, дані по параметру РВК відображено в таблицях.

Таблиця 3 - Рівень вербальної креативності у психологів експериментальної групи

\begin{tabular}{|c|c|c|c|}
\hline $\begin{array}{c}\text { Рівень } \\
\text { вербальної } \\
\text { креативності }\end{array}$ & 1 етап дослідження & 2 етап дослідження & 3 етап дослідження \\
\hline 1 & 0 & 1 & 6 \\
\hline 2 & 6 & 8 & 12 \\
\hline 3 & 11 & 11 & 3 \\
\hline 4 & 4 & 2 & 2 \\
\hline 5 & 4 & 3 & 0 \\
\hline 6 & 0 & 0 & 0 \\
\hline
\end{tabular}

Якщо на початковому - першому етапі: 2 рівень був у 6 психологів, 3 рівень - у 11 психологів, 4 - у 4 психологів, 5 - у 4 психологів; то на другому етапі з'являється вже 1 рівень - 1 психолог, на 2 рівні ми бачимо вже 8 психологів, на 3 рівні - 11, на 4 - 2 психолога, на 5 рівні - 3 психолога. На третьому етапі дослідження- на 1 рівні - 6 психологів, на 2 - 12, на 3 рівні -3 психолога, на 4 рівні - 2 психолога, а психологів з показниками 6 рівня вже не спостерігається. Це дозволяє нам зробити висновок про те, що тенденція до розвитку вербальної креативності простежується у психологів експериментальної групи, на яку впливали за допомогою мотиваційного чинника - новизни діяльності.

Таблиця 4 - Рівень вербальної креативності у психологів контрольної групи

\begin{tabular}{|c|c|c|c|}
\hline $\begin{array}{c}\text { Рівень } \\
\text { вербальної } \\
\text { креативності }\end{array}$ & 1етап дослідження & 2 етап дослідження & 3 етап дослідження \\
\hline 1 & 0 & 0 & 0 \\
\hline 2 & 0 & 0 & 2 \\
\hline 3 & 33 & 6 & 18 \\
\hline 4 & 20 & 17 & 5 \\
\hline 5 & 2 & 2 & 0 \\
\hline 6 & 0 & 0 & 0 \\
\hline
\end{tabular}

Результати контрольної групи по параметрах вербальної креативності дають нам уявлення про те, як у ході професійної діяльності розвивається самоактуалізація особистості. Підвищення рівня самоактуалізації спостерігається, але воно не таке продуктивне, 
як в експериментальній групі, на якій впливали мотиваційним засобом - новизною діяльності.

Ще однією складовою параметра розвитку самоактуалізації особистості $\epsilon$ рівень невербальної креативності (РНК). Показники цього рівня ми отримали в ході дослідження при обробці результатів тестової методики $Є$. Торранса. Дані експериментальної групи представлено в таблиці 5, а контрольної - в таблиці 6. Ми бачимо, що рівень невербальної креативності на кожному наступному етапі експерименту стає вищим. На першому етапі дослідження: Зрівень простежується в 1 психолога, 4- у 9 психологів, 5- у 10 психологів, 6 - у 5 психологів.

Таблиця 5 - Рівень невербальної креативності у психологів експериментальної групи

\begin{tabular}{|c|c|c|c|}
\hline $\begin{array}{c}\text { Рівень } \\
\text { невербальної } \\
\text { креативності }\end{array}$ & $\mathbf{1}$ етап дослідження & $\mathbf{2}$ етап дослідження & 3 етап дослідження \\
\hline 1 & 0 & 0 & 0 \\
\hline 2 & 0 & 0 & 1 \\
\hline 3 & 1 & 2 & 9 \\
\hline 4 & 9 & 13 & 0 \\
\hline 5 & 10 & 2 & 3 \\
\hline 6 & 5 & & \\
\hline
\end{tabular}

На другому етапі дослідження: на 3 рівні - 2 психолога, на 4рівні - 13 психологів, на 5-8 психологів, на 6 рівні- 2 психолога. На третьому етапі дослідження рівень підвищується: на 2 рівні - 1 психолог, на 3-12 психологів, на 4-9 психологів, на 5 рівні -3 психолога, а показників
6 рівня вже немає. Цей результат говорить про те, що тенденція до розвитку параметра невербальної креативності простежується у психологів експериментальної групи, на яку впливали за допомогою мотиваційного чинника - новизни діяльності.

Таблиця 6- Рівень невербальної креативності у психологів контрольної групи

\begin{tabular}{|c|c|c|c|}
\hline $\begin{array}{c}\text { Рівень } \\
\text { невербальної } \\
\text { креативності }\end{array}$ & 1 етап дослідження & 2 етап дослідження & 3 етап дослідження \\
\hline 1 & 0 & 0 & 0 \\
\hline 2 & 0 & 0 & 2 \\
\hline 3 & 33 & 6 & 5 \\
\hline 4 & 20 & 17 & 0 \\
\hline 5 & 2 & 2 & 0 \\
\hline 6 & 0 & 0 & 18 \\
\hline
\end{tabular}

Результати контрольної групи за параметрами невербальної креативності, показують несуттєві зміни у самоактуалізації особистості, які відбуваються з психологами в процесі професійної діяльності протягом навчального року. Вони менш помітні порівняно з експериментальною групою.
Далі ми розглянемо параметри рівня розвитку самоактуалізації особистості, що складається у свою чергу з показників рівня творчого потенціалу, рівня вербальної креативності й рівня невербальної креативності. 
Таблиця 7 - Рівень самоактуалізаціїпсихологів експериментальної групи

\begin{tabular}{|c|c|c|c|}
\hline $\begin{array}{c}\text { Рівень } \\
\text { самоактуалізації }\end{array}$ & 1 етап дослідження & 2 етап дослідження & 3 етап дослідження \\
\hline 1 & 0 & 0 & 0 \\
\hline 2 & 0 & 0 & 6 \\
\hline 3 & 6 & 11 & 16 \\
\hline 4 & 14 & 12 & 3 \\
\hline 5 & 5 & 2 & 0 \\
\hline 6 & 0 & 0 & 0 \\
\hline
\end{tabular}

В таблиці 7 показані параметри розвитку самоактуалізації особистості для експериментальної групи, на яку впливали мотиваційним засобом - новизною діяльності, а в таблиці8 відображені результати параметра розвитку самоактуалізації особистості в контрольній групі. Отже, на початковому першому етапі нашого експерименту: 3 рівень був у 6 психологів, 4 - у 14 психологів , 5- у 5 психологів. На другому етапі дослідження: на Зрівні вже 11 психологів, на 4-12 психологів, на 5 рівні - 2 психолога. На третьому етапі дослідження рівень підвищується: на 2 рівні -6 психологів, на 3- у 16 психологів, на 4рівні - 3 психолога, а фахівців з показником 6 рівня вже немає.

Таблиця 8- Рівень самоактуалізації у психологів контрольної групи

\begin{tabular}{|c|c|c|c|}
\hline $\begin{array}{c}\text { Рівень } \\
\text { самоактуалізації }\end{array}$ & 1 етап дослідження & 2 етап дослідження & 3 етап дослідження \\
\hline 1 & 0 & 0 & 0 \\
\hline 2 & 0 & 0 & 2 \\
\hline 3 & 33 & 6 & 18 \\
\hline 4 & 20 & 17 & 5 \\
\hline 5 & 2 & 2 & 0 \\
\hline 6 & 0 & 0 & 0 \\
\hline
\end{tabular}

Із цього можна зробити висновки, що за допомогою мотиваційного чинника новизни діяльності ми розвиваємо самоактуалізацію особистості, що й підтвердилося в ході емпіричного дослідження. Ми бачимо, що параметри рівня розвитку самоактуалізації у психологів експериментальної групи, на яку впливали мотиваційним засобом - новизною діяльності, підвищується на кожному наступному етапі експерименту. Простежуючи результати контрольної групи, можна відзначити, що параметри рівня розвитку самоактуалізації у психологів підвищується, але не так чітко, як це простежується в експериментальній групі. Дещо зростає показник 3 рівня, підвищується також у свою чергу 4 і 5 рівні, але це не явно виражено. Отже, можемо говорити про те, що в процесі професійної діяльності середній рівень самоактуалізації підвищується, але це малопомітно і несуттєво.

За отриманими результатами можна зробити висновки, що мотиваційний чинник новизна діяльності - впливає на розвиток самоактуалізації особистості й ефективніше результати видно після спеціально проведених тренінгів. Для математичної обробки результатів, отриманих у процесі експерименту, за допомогою G-критерію знаків визначено, типовим чи випадковим є напрямок зрушення результатів параметрів самоактуалізації особистості на всіх етапах експерименту. Для цього приведемо таблицю параметрів самоактуалізації особистості (СО) для мотиваційного чинника - новизни діяльності, використовуваного нами для розвитку самоактуалізації психологів (табл. 9).

Використовуючи G-критерій знаків для 
встановлення загального напрямку зрушення СО для мотиваційного чинника - новизни діяльності в розвитку самоактуалізації особистості, висуваємо наступні робочі гіпотези:

Нульова: Перевага типового напрямку зрушення є випадковою.

Зворотна: Перевага типового напрямку зрушення не $є$ випадковою.

Для виявлення типових змін результатів параметра СO, підрахуємо спочатку кількість позитивних, негативних і нульових зрушень по кожній шкалі й у кожній вибірці. Результати для підрахунку G-критерію представлені нами в таблиці 10. Для мотиваційного чинника новизни діяльності - емпіричне значення $\mathrm{O}_{\text {емп. }}=$ 0 , а критичні значення для 1 зрушення $=16$. Отже, нульова гіпотеза відкидається, а затверджується зворотна гіпотеза з рівнем значимості $p<0,01$.

Таблиця 9- Значення параметрів СО на трьох етапах експерименту групи, на яку впливали мотиваційним засобом - новизною діяльності

\begin{tabular}{|c|c|c|c|c|c|}
\hline № психолога & $\begin{array}{c}\text { СО } \\
1 \text { етап }\end{array}$ & $\begin{array}{c}\text { СО } \\
2 \text { етап }\end{array}$ & $\begin{array}{c}\text { Со } \\
3 \text { етап }\end{array}$ & $\begin{array}{c}\text { CO2-СO1 } \\
\text { (зрушення 1) }\end{array}$ & $\begin{array}{c}\mathrm{CO3-CO2} \\
\text { (зрушення 2) }\end{array}$ \\
\hline 1 & 3,67 & 3,67 & 2,67 & 0,00 & $-1,00$ \\
\hline 2 & 3,33 & 2,67 & 2,33 & $-0,67$ & $-0,33$ \\
\hline 3 & 4,00 & 3,67 & 3,00 & $-0,33$ & $-0,67$ \\
\hline 4 & 4,67 & 4,33 & 3,67 & $-0,33$ & $-0,67$ \\
\hline 5 & 4,00 & 3,33 & 2,67 & $-0,67$ & $-0,67$ \\
\hline 6 & 4,33 & 3,67 & 3,00 & $-0,67$ & $-0,67$ \\
\hline 7 & 3,67 & 3,00 & 2,33 & $-0,67$ & $-0,67$ \\
\hline 8 & 5,00 & 4,67 & 3,67 & $-0,33$ & $-1,00$ \\
\hline 9 & 4,67 & 4,00 & 3,33 & $-0,67$ & $-0,67$ \\
\hline 10 & 4,67 & 4,33 & 3,33 & $-0,33$ & -1.00 \\
\hline 11 & 4,33 & 4,00 & 3,33 & $-0,33$ & $-0,67$ \\
\hline 12 & 3,67 & 3,33 & 2,67 & $-0,33$ & $-0,67$ \\
\hline 13 & 3,33 & 3,33 & 2,33 & 0,00 & $-1,00$ \\
\hline 14 & 3,33 & 3,33 & 2,33 & 0,00 & $-1,00$ \\
\hline 15 & 4,00 & 3,67 & 2,67 & $-0,33$ & $-1,00$ \\
\hline 16 & 4,33 & 3,67 & 3,33 & $-0,67$ & $-0,33$ \\
\hline 17 & 4,67 & 4,67 & 3,67 & 0,00 & $-1,00$ \\
\hline 18 & 4,00 & 3,33 & 2,67 & $-0,67$ & $-0,67$ \\
\hline 19 & 4,33 & 3,67 & 3,33 & $-0,67$ & $-0,33$ \\
\hline 20 & 3,33 & 3,33 & 2,67 & 0,00 & $-0,67$ \\
\hline 21 & 4,33 & 4,33 & 3,00 & 0,00 & $-1,33$ \\
\hline 22 & 3,33 & 3,33 & 2,33 & 0,00 & $-1,00$ \\
\hline 23 & 3,33 & 3,33 & 2,33 & 0,00 & $-1,00$ \\
\hline 24 & 3,67 & 3,67 & 2,67 & 0,00 & $-1,00$ \\
\hline 25 & 3,67 & 3,00 & 2,67 & $-0,67$ & $-0,33$ \\
\hline
\end{tabular}

Статистично вірогідно, що отримані що рівень розвитку самоактуалізації особистості параметри зменшуються, це говорить про те, стає вище. 
Таблиця 10 - Розрахунок кількості позитивних, негативних і нульових зрушень у процесі впливу мотиваційним засобом - новизною діяльності на розвиток СО на етапах експерименту

\begin{tabular}{|l|c|c|}
\hline \multicolumn{1}{|c|}{$\begin{array}{c}\text { Кількість зрушень у } \\
\text { групах }\end{array}$} & \multicolumn{2}{|c|}{ Шкали } \\
\hline & CO2-СО1 (зрушення 1) & CO3-СО2 (зрушення 2) \\
\hline Позитивні & 16 & 22 \\
\hline Негативні & 0 & 0 \\
\hline Нульові & 9 & 3 \\
\hline Сума & 25 & 25 \\
\hline
\end{tabular}

Отже, мотиваційний чинник - новизна діяльності - розвиває самоактуалізацію

\section{Висновки}

Емпіричним шляхом визначено, що само актуалізація проявляється на певному сприятливому психологічному тлі. Як з'ясувалося в результаті проведеного емпіричного дослідження, виділені нами мотиваційні засоби впливають на розвиток самоактуалізації психологів, а саме, спостерігається ріст параметрів самоактуалізації особистості після впливу на неї мотиваційним чинником новизни діяльності.

Із цього можна зробити висновки, що за допомогою мотиваційного чинника новизни діяльності ми розвиваємо самоактуалізацію особистості, що й підтвердилося в ході емпіричного дослідження. Ми визначили, що параметри рівня розвитку самоактуалізації у особистості, а саме, спостерігається ріст параметрів самоактуалізації психологів.

\section{Список використаних джерел}

1. Артемова О. І. Професійна самореалізація особистості в сучасних умовах // Освіта регіону. - №1.2010. - С. 97-101.

2. Василенко А. Ю. Самоактуализация личности как фактор профессиональной вовлечённости субъекта// Вектор науки ТГУ. - №1(8). - 2018. - С. 83-86.

3. Гомонюк В. О. Самоактуалізація та самореалізація особистості: сучасні наукові уявлення // “Психология и социология" / 10. Психология труда: [Електронний ресурc]. URL: http://

психологів експериментальної групи, на яку впливали мотиваційним засобом - новизною діяльності, підвищується на кожному наступному етапі експерименту. Простежуючи результати контрольної групи, можна відзначити, що параметри рівня розвитку самоактуалізації у психологів підвищується, але не так чітко, як це простежується в експериментальній групі. Отже, можемо говорити про те, що в процесі професійної діяльності середній рівень самоактуалізації підвищується, але це малопомітно і несуттєво.

В подальшому пропонується провести дослідження впливу середовища на самоактуалізацію фахівця. http://www.rusnauka.com

4. Сафронова О. В. Проблема самоактуализации личности в психологопедагогической литературе / О. В. Сафронова // Вестник ЧГПУ. - 2017. - №1. - C.132-139.

5. Ткалич М. Г. Психолого-організаційні детермінанти самоактуалізації менеджерів комерційних організацій: Автореф. дис... канд. психол. наук: 19.00.10 / М.Г. Ткалич; Ін-т психології ім. Г.С. Костюка АПН України. - К., 2006. - 20 с. 


\title{
Эмпирическое исследование влияния новизны деятельности
}

\section{на развитие самоактуализации психолога}

\author{
Олег Бабелюк * А; Наталья Гоцуляк А; Владимир Израйлов ${ }^{\text {; }}$ \\ Алексей Шкуренко ${ }^{B}$ \\ *Corresponding author: кандидат психологических наук, преподаватель кафедры военной подготовки, e-mail: babeliyk@ukr.net \\ А Каменец-Подольский национальный университет имени Ивана Огиенко, улица Огиенко, 61, Каменец-Подольский, 32301, Украина

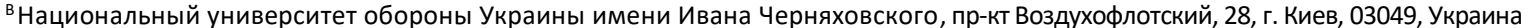

\begin{abstract}
Аннотация
Статья посвящена установлению взаимосвязи между новизной деятельности и уровнем развития самоактуализации психолога. Проведен анализ научных работ в этой области и определено, что самоактуализация - это психологических процесс, при котором способности человека применяются полностью и творчески, а также самоактуализация дает человеку чувство удовлетворенности уровнем жизни.

Авторами предлагаются концептуальные подходы к исследованию влияния различных факторов на развитие самоактуализации профессионала. Говоря о роли новизны деятельности, авторы исследования отмечают проблему информационного конфликта.

Термин "информационный конфликт" обозначает познавательное состояние субъекта в ситуации идентификации, или отнесения его к категории стимульной конфигурации, части которой находятся в противоречии друг с другом.

Согласно полученным результатам, авторы сделать вывод, что мотивационный фактор новизна деятельности - влияет на развитие самоактуализации личности и эффективнее результаты видны после специально проводимых ими тренингов. В дальнейшем предлагается провести исследование влияния среды на самоактуализацию специалиста.
\end{abstract}

Ключевые слова: деятельность, самоактуализация, креативность, информационный конфликт, психолог, личность.

\section{Empirical study of the influence of novelty on the development of psychologist's self-actualization}

\author{
Oleh Babeliuk * A; Natalia Hotsuliak ${ }^{\text {A; }}$ Volodymyr Izraylov ${ }^{\text {B; }}$ Oleksii Shkurenko ${ }^{\text {B }}$ \\ *Corresponding author: Candidate of Psychological Sciences, Lecturer of the Department of Military Training, e-mail: babeliyk@ukr.net \\ A Kamianets-Podilskyi Ivan Ohiienko National University, 61 Ogienko Str., Kamyanets-Podilsky, 32301, Ukraine \\ ${ }^{B}$ National Defence University of Ukraine named after Ivan Cherniakhovskyi, 28, Povitroflotskyi Ave, Kyiv, 03049, Ukraine
}

\begin{abstract}
The article is devoted to establishing the relationship between the novelty of the activity and the level of development of self-actualization of the psychologist.

The analysis of scientific works in this field is carried out and it is determined that self-actualization is a psychological process in which human abilities are used fully and creatively, and self-actualization gives a person a sense of satisfaction in life.

The authors propose conceptual approaches to the empirical study of the influence of various factors on the development of professional self-actualization.

Speaking about the role of novelty, the authors of the study emphasize the problem of information conflict. The term "information conflict" refers to the cognitive state of the subject in a situation of identification, or its classification as a stimulus configuration, parts of which do not agree with each other, being in a state of rigid contradiction.
\end{abstract}


Based on the results, the authors conclude that the motivating factor - the novelty of the activity affects the development of self-actualization of the individual and the results are more effective after special training.

In the future, it is proposed to conduct a study of the impact of the environment on the selfactualization of the specialist.

Keywords: activity, self-actualization, creativity, information conflict, psychologist, personality.

\section{References}

1. Artemova O. I. (2010) Professional selfrealization of the individual in modern conditions. Education of the region. №1. P. 97101. [in Ukraine]

2. Vasilenko A. Yu. (2018) Self-actualization of personality as a factor of professional involvement of the subject. Vector of science. №1 (8). P. 83-86. [in Ukraine]

3. Homonyuk V. O. Self-actualization and selfrealization of personality: modern scientific ideas // Psychology and sociology / №10. Psychology of labor: [Electronic resource] // Access mode: http: // http://www.rusnauka.com

4. Safronova O. V. (2017) The problem of selfactualization of personality in psychological and pedagogical literature. Vestnik. №1. P.132-139. [in Ukraine]

5. Tkalich M. H. Psychological and organizational determinants of self-actualization of managers of commercial organizations: Abstract. dis ... cand. psychol. Science: 19.00.10 / M.H. Tkalich; Institute of Psychology. H. S. Kostyuk Academy of Pedagogical Sciences of Ukraine. Kyiv, 2006. 20 p. [in Ukraine] 